\title{
Epstein-Barr Virus Lytic Reactivation Induces IgG4 Production by Host B Lymphocytes in Graves' Disease Patients and Controls: A Subset of Graves' Disease Is an IgG4-Related Disease-Like Condition
}

\author{
Keiko Nagata, Sayuri Hara,, Yuji Nakayama,2 Katsumi Higaki, Hirotsugu Sugihara,, Satoshi Kuwamoto, \\ Michiko Matsushita, ${ }^{3}$ Masako Kato, Shunsuke Tanio,, Kiyosuke Ishiguro, and Kazuhiko Hayashi ${ }^{1}$
}

\begin{abstract}
Immunoglobulin (Ig) G4-related disease (IgG4-RD) is a newly recognized systemic fibroinflammatory disease with characteristic histological findings and high serum IgG4 levels. Epstein-Barr virus (EBV) is a persistent herpesvirus in B lymphocytes, and we previously reported EBV reactivation-induced Ig production. We showed that EBV reactivation induced the production of thyrotropin receptor antibodies, the causative antibodies of Graves' disease. In the present study, we investigated whether EBV reactivation induced IgG4 production and if EBV-positive B cells or IgG4-positive plasma cells are present in the thyroid tissues of Graves' disease patients with lymphoplasmacytic infiltration. EBV-encoded small RNA1 (EBER1) in situ hybridization and immunohistochemistry for IgG and IgG4 were performed on seven resected thyroid tissues with lymphoplasmacytic infiltration collected from the thyroids of 11 Graves' disease patients. We then cultured the lymphocytes of 13 Graves' disease patients and 14 controls and induced EBV reactivation to measure IgG4 levels in culture fluids. We detected EBER1-positive cells and IgG4positive plasma cells in the same area of thyroid tissues. EBV-reactivated cells with IgG4 on their surface were observed in culture cells, and IgG4 production was detected in culture fluids. The IgG4/IgG percentage was higher than that in normal serum level. A subset of Graves' disease is an IgG4-RD-like condition, not an IgG4-RD. EBV reactivation stimulates IgG4 production, which may result in high serum IgG4 levels and promote IgG4-positive plasma cell infiltration. EBER1 needs to be examined when an increase in IgG4-positive plasma cell numbers is noted.
\end{abstract}

Keywords: Epstein-Barr virus, Epstein-Barr virus reactivation, IgG4-related disease, Graves' disease, Epstein-Barr virus-encoded small RNA1

\section{Introduction}

I MMUNOGLOBULIN (Ig) G4-related disease (IgG4-RD) is a systemic fibroinflammatory disease that is characterized by tumefactive lesions, storiform fibrosis, obliterative phle- bitis, and a lymphoplasmacytic infiltrate with IgG4-positive plasma cells $(6,29)$. It is typically accompanied by high serum IgG4 levels. Several diseases including autoimmune pancreatitis and Mikulicz's syndrome have been recognized as IgG4-RD. However, an increasing number of diseases and

\footnotetext{
${ }^{1}$ Division of Molecular Pathology, Department of Pathology, Faculty of Medicine, Tottori University, Yonago, Japan.

${ }^{2}$ Division of Functional Genomics, Research Center for Bioscience and Technology, Tottori University, Yonago, Japan.

${ }^{3}$ Department of Pathobiological Science and Technology, School of Health Science, Faculty of Medicine, Tottori University, Yonago, Japan.

${ }^{4}$ Division of Oral and Maxillofacial Biopathological Surgery, Department of Medicine of Sensory and Motor Organs, Faculty of Medicine, Tottori University, Yonago, Japan.

${ }^{5}$ Division of Organ Regeneration Surgery, Department of Surgery, Faculty of Medicine, Tottori University, Yonago, Japan.

(C) Keiko Nagata et al. 2018; Published by Mary Ann Liebert, Inc. This Open Access article is distributed under the terms of the Creative Commons Attribution Noncommercial License (http://creativecommons.org/licenses/by-nc/4.0/) which permits any noncommercial use, distribution, and reproduction in any medium, provided the original author(s) and the source are cited.
} 
conditions without histological characteristics were found to have high serum IgG4 levels and the infiltration of IgG4positive plasma cells; therefore, difficulties are associated with diagnosing true IgG4-RD.

IgG4 is a low-affinity antibody (35) that weakly binds to $\mathrm{Fc} \gamma$ receptors (2) and does not bind to complement 1q (5). The location and mechanisms by which IgG4 is produced have not yet been elucidated. It also remains unclear whether IgG4 contributes to the pathogenesis of IgG4-RD or is only produced as a consequence of the disease. Furthermore, the involvement of autoimmune mechanisms in the development of IgG4-RD is still debatable $(5,13,29)$.

Epstein-Barr virus (EBV) is a common human herpesvirus that latently infects most adults (16). EBV stably infects, but sometimes changes its mode of infection from latent to lytic, and this is referred to as reactivation $(3,11)$. EBV mainly infects B lymphocytes and thus is speculated to affect the antibody production by host B cells. Various serum autoantibodies have been observed in the acute phase of infectious mononucleosis $(8,21)$, which suggests a relationship between EBV and autoimmunity.

Graves' disease was reported to show high serum IgG4 in some cases (31). We previously demonstrated the presence of EBV-infected B cells with a thyrotropin receptor antibody (TRAb) as the surface globulin [TRAb(+)EBV(+) cells] in peripheral blood mononuclear cells (PBMCs) from Graves' disease patients and controls (19). TRAbs are causative autoantibodies of Graves' disease. We induced EBV reactivation on PBMCs containing TRAb(+)EBV(+) cells and observed the production of IgG, IgM, IgE, and TRAb as well as the ex- pression of activation-induced cytidine deaminase (AID) and its mRNA (AICDA) (Fig. 1) $(20,22)$. Our findings suggested that $E B V$ reactivation stimulates plasma cell differentiation of host B cells and Ig production. Therefore, we proposed an EBV reactivation-induced Ig production mechanism (Fig. 1): (1) EBV infection and polyclonal B cell activation, (2) AID expression and class-switch recombination (CSR), and (3) EBV reactivation, plasma cell differentiation, and Ig production. The Igs produced may be low in affinity for antigens, but some show an isotype change from the IgM on naive B cells.

We herein examined the presence of IgG4-positive plasma cells and EBV-infected cells in resected thyroid tissue of Graves' disease and investigated whether IgG4 is produced by an EBV reactivation-induced Ig production mechanism in Graves' disease patients and controls.

\section{Materials and Methods}

\section{Subjects}

Twenty-four Graves' disease patients and 14 healthy controls participated in the present study (Tables 1 and 2). All subjects provided written informed consent for participation in the study, and the study protocol was approved by the Medical Ethics Committee for Human Subject Research (No. 707, 707-1-13) at the Faculty of Medicine, Tottori University, Yonago, Japan. Eleven patients had also participated in our previous study (22).

Eleven of the 24 patients underwent thyroidectomy. Nine of the 13 patients without surgery were receiving treatments with antithyroid drugs (methylmercaptoimidazole or

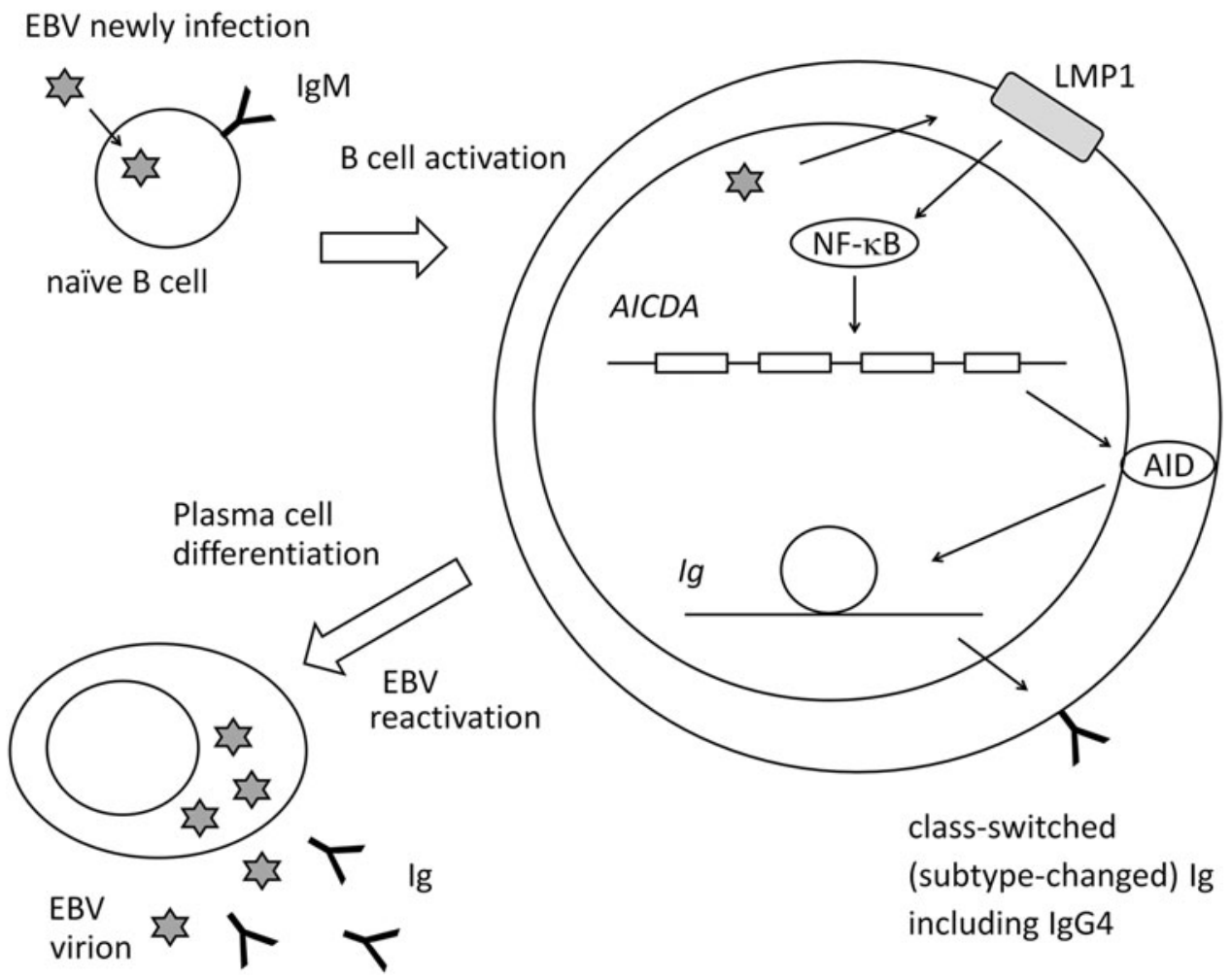

FIG. 1. Pathway for EBV reactivation-induced Ig production. B cells newly infected by EBV become latency 3 and express LMP1. LMP1 activates host cells (polyclonal B cell activation). LMP1 stimulates AID expression through NF- $\kappa$ B, which enables host cells to class-switch Ig. EBV reactivation induces plasma cell differentiation and Ig production. AID, activation-induced cytidine deaminase; EBV, Epstein-Barr virus; Ig, immunoglobulin; NF- $\kappa \mathrm{B}$, nuclear factor-kappa B. 
Table 1. Profiles, Ig Production, and AICDA mRNA Expression of Controls and Patients Without Surgery

\begin{tabular}{|c|c|c|c|c|c|c|c|c|c|c|c|c|}
\hline \multirow[b]{3}{*}{$\begin{array}{l}\text { Sample } \\
\text { no. }\end{array}$} & \multirow[b]{3}{*}{$\begin{array}{l}\text { Age, } \\
\text { years }\end{array}$} & \multirow[b]{3}{*}{ Sex } & \multicolumn{2}{|c|}{ Serum } & \multicolumn{4}{|c|}{ Culture medium } & \multicolumn{3}{|c|}{$\begin{array}{l}\text { Culture medium } \\
\text { (previous report) }\end{array}$} & \multirow{2}{*}{$\begin{array}{c}\text { mRNA (previous } \\
\text { report) } \\
\text { Mean of the sample period }\end{array}$} \\
\hline & & & \multirow[b]{2}{*}{$\begin{array}{l}\text { TRAb, } \\
I U / L\end{array}$} & \multirow[b]{2}{*}{$\begin{array}{l}I g G 4, \\
m g / d L\end{array}$} & \multirow[t]{2}{*}{ Day 0} & \multicolumn{3}{|c|}{ Day 5 Day 10 Day 12} & \multicolumn{3}{|c|}{ Mean of the sample period } & \\
\hline & & & & & & $\operatorname{IgG} 4$, & $n g / m L$ & & $\begin{array}{c}\operatorname{Ig} G \\
n g / m L\end{array}$ & $\begin{array}{c}I g M \\
n g / m L\end{array}$ & $\begin{array}{c}\operatorname{IgE} E \\
n g / m L\end{array}$ & $\begin{array}{l}\text { AICDA relative } \\
\text { quantity to } \beta \text {-actin }\end{array}$ \\
\hline \multicolumn{13}{|c|}{ Controls } \\
\hline 1 & 25 & M & 1.1 & 7.24 & 0.00 & 1.50 & 0.00 & 0.30 & 8.22 & 35.30 & 9.89 & 0.00 \\
\hline 2 & 41 & $\mathrm{~F}$ & 0.81 & 48.08 & 0.00 & 2.70 & 0.15 & 0.00 & 10.08 & 34.26 & 9.51 & 0.01 \\
\hline 3 & 53 & $\mathrm{~F}$ & 0.5 & 8.24 & 0.30 & 4.96 & 0.00 & 2.56 & 8.89 & 34.73 & 8.91 & 0.01 \\
\hline 4 & 32 & $\mathrm{~F}$ & 0.51 & 13.09 & 0.30 & 3.76 & 0.15 & 1.65 & 8.71 & 34.49 & 8.91 & 0.01 \\
\hline 5 & 24 & $\mathrm{~F}$ & 0.45 & 17.28 & 0.00 & 4.51 & 1.66 & 0.15 & 19.26 & 63.62 & 8.37 & 0.01 \\
\hline 6 & 57 & $\mathrm{M}$ & 0.79 & 12.98 & 0.00 & 2.10 & 0.00 & 1.05 & 9.12 & 32.36 & 8.75 & 0.05 \\
\hline 7 & 34 & M & 0.42 & 0.8 & 0.90 & 3.46 & 1.96 & 3.16 & 25.72 & 34.34 & 8.86 & 0.04 \\
\hline 8 & 52 & $\mathrm{~F}$ & 0.63 & 29.23 & 6.91 & 2.86 & 3.16 & 1.36 & 12.87 & 35.75 & 8.91 & 0.01 \\
\hline 9 & 36 & $\mathrm{M}$ & 0.43 & 4.44 & 7.51 & 3.76 & 4.36 & 2.26 & 10.83 & 35.80 & 8.59 & 0.08 \\
\hline 10 & 23 & $\mathrm{~F}$ & 0.61 & 0.38 & 1.50 & 0.00 & 0.00 & 0.00 & 10.98 & 32.48 & 8.20 & 0.02 \\
\hline 11 & 23 & $\mathrm{~F}$ & 0.65 & 9.98 & 1.50 & 1.95 & 0.00 & 0.00 & 9.34 & 31.41 & 8.05 & 0.05 \\
\hline 12 & 29 & $\mathrm{~F}$ & 0.8 & 83.72 & 1.89 & 8.12 & 0.00 & 0.00 & NT & NT & NT & NT \\
\hline 13 & 42 & $\mathrm{~F}$ & 0.88 & 18.02 & 19.85 & 9.92 & 8.90 & 0.00 & NT & NT & NT & NT \\
\hline 14 & 31 & $\mathrm{~F}$ & 0.46 & 97.36 & 18.83 & 8.38 & 5.72 & 1.75 & NT & NT & NT & NT \\
\hline \multicolumn{13}{|l|}{ Patients } \\
\hline 1 & 32 & $\mathrm{~F}$ & 0.95 & 0.47 & 1.50 & 0.75 & 0.00 & 0.00 & 8.87 & 31.39 & 8.09 & 0.03 \\
\hline 2 & 39 & $\mathrm{~F}$ & 12.97 & 8.34 & 1.50 & 4.36 & 0.00 & 0.00 & 18.50 & 30.88 & 7.59 & 0.02 \\
\hline 3 & 47 & $\mathrm{~F}$ & 6.93 & 16.34 & 2.70 & 3.16 & 0.00 & 0.00 & 22.63 & 42.96 & 7.94 & 0.06 \\
\hline 4 & 51 & $\mathrm{~F}$ & 17.23 & 17.24 & 0.90 & 3.46 & 0.15 & 0.00 & 8.74 & 30.29 & 7.92 & 0.02 \\
\hline 5 & 47 & $\mathrm{~F}$ & 0.9 & 48.36 & 2.70 & 0.75 & 1.05 & 0.00 & 10.85 & 32.38 & 7.77 & 0.02 \\
\hline 6 & 58 & $\mathrm{~F}$ & 5.36 & 17.33 & 1.50 & 3.16 & 1.36 & 0.00 & 9.35 & 35.13 & 8.93 & 0.02 \\
\hline 7 & 48 & $\mathrm{~F}$ & 1.59 & 0.86 & 3.31 & 2.86 & 3.46 & 0.00 & 19.64 & 35.76 & 8.58 & 0.02 \\
\hline 8 & 39 & $\mathrm{~F}$ & 0.74 & 16.77 & 5.71 & 4.06 & 5.26 & 0.00 & 7.88 & 31.94 & 12.02 & 0.01 \\
\hline 9 & 35 & $\mathrm{~F}$ & 0.79 & 5.44 & 0.30 & 0.00 & 0.00 & 0.30 & 8.29 & 32.43 & 11.39 & 0.01 \\
\hline 10 & 45 & $\mathrm{~F}$ & 1.14 & 10.69 & 15.69 & 8.90 & 11.47 & 13.89 & NT & NT & NT & NT \\
\hline 11 & 31 & $\mathrm{~F}$ & 1.73 & 7.01 & 19.85 & 17.68 & 18.32 & 2.76 & NT & NT & NT & NT \\
\hline 12 & 29 & $\mathrm{~F}$ & 0.9 & 42.52 & 11.33 & 2.34 & 8.44 & 0.00 & NT & NT & NT & NT \\
\hline 13 & 39 & $\mathrm{~F}$ & 0.57 & 97.71 & 3.13 & 3.99 & 18.08 & 10.43 & NT & NT & NT & NT \\
\hline
\end{tabular}

AICDA, mRNA of activation-induced cytidine deaminase (AID); NT, not tested; TRAb, thyrotropin receptor antibody.

Table 2. Profiles, Immunohistochemistry, and In Situ Hybridization of Patients Who Underwent Surgery

\begin{tabular}{|c|c|c|c|c|c|c|c|c|c|}
\hline \multirow[b]{2}{*}{$\begin{array}{l}\text { Subsets of Graves' } \\
\text { disease patients }\end{array}$} & \multirow[b]{2}{*}{$\begin{array}{l}\text { Sample no. } \\
\text { (patients) }\end{array}$} & \multirow[b]{2}{*}{$\begin{array}{l}\text { Age, } \\
\text { years }\end{array}$} & \multirow[b]{2}{*}{ Sex } & \multicolumn{2}{|c|}{ Serum } & \multicolumn{3}{|c|}{ Tissue preparation } & \multirow[b]{2}{*}{$\begin{array}{c}\text { EBERI } \\
\text { ISH }\end{array}$} \\
\hline & & & & $\begin{array}{c}T R A b \\
I U / L\end{array}$ & $\begin{array}{l}\operatorname{IgG} 4 \\
m g / d L\end{array}$ & $\begin{array}{c}\operatorname{IgG} 4(+) \\
\text { plasma cells, } \\
\text { cells/HPF }\end{array}$ & $\begin{array}{c}\operatorname{IgG}(+) \\
\text { plasma cells, } \\
\text { cells/HPF }\end{array}$ & $\begin{array}{l}\operatorname{Ig} G 4 / \\
\operatorname{IgG}, \%\end{array}$ & \\
\hline \multirow[t]{7}{*}{ Lymphocyte infiltration $(+)$} & 14 & 22 & $\mathrm{~F}$ & $40<$ & 129.71 & 55.3 & 139.0 & 39.8 & + \\
\hline & 15 & 28 & $\mathrm{~F}$ & $40<$ & 195.61 & 42.5 & 49.5 & 85.9 & + \\
\hline & 16 & 34 & $\mathrm{~F}$ & 2.2 & $200<$ & 64.7 & 110.7 & 58.4 & + \\
\hline & 17 & 40 & $\mathrm{M}$ & $40<$ & $200<$ & 50.0 & 86.5 & 57.8 & + \\
\hline & 18 & 26 & $\mathrm{M}$ & 24.2 & 104.55 & 55.0 & 67.3 & 81.7 & + \\
\hline & 19 & 51 & $\mathrm{~F}$ & $40<$ & 82.05 & 7.0 & 14.3 & 48.8 & + \\
\hline & 20 & 61 & $\mathrm{~F}$ & NT & NT & 45.7 & 111.3 & 41.0 & + \\
\hline \multirow[t]{4}{*}{ Lymphocyte infiltration $(+/-)$} & 21 & 72 & $\mathrm{~F}$ & $40<$ & 77.29 & NT & NT & NT & NT \\
\hline & 22 & 37 & $\mathrm{~F}$ & 10.4 & 23.14 & NT & NT & NT & NT \\
\hline & 23 & 46 & $\mathrm{~F}$ & 13 & 47.32 & NT & NT & NT & NT \\
\hline & 24 & 51 & $\mathrm{~F}$ & NT & $\mathrm{NT}$ & NT & NT & NT & NT \\
\hline
\end{tabular}

Each plasma cell count is an average of three corresponding fields for IgG4 and IgG.

EBER1, Epstein-Barr virus-encoded small RNA 1; ISH, in situ hybridization; lymphocyte infiltration (+), hyperplastic thyroid with moderate lymphoplasmacytic infiltration; lymphocyte infiltration $(+/-)$, hyperplastic thyroid with no or few lymphoplasmacytic infiltration; TRAb, thyrotropin receptor antibody; HPF, high power field; NT, not tested. 
propylthiouracil). Control subjects voluntarily enrolled. Their thyroid functions were normal, and they had no family history of thyroid disease.

The mean ages $( \pm \mathrm{SD})$ of Graves' disease patients treated with thyroidectomy (11 cases; Table 2$)$, those treated with antithyroid drugs (nonsurgical group) (13 cases; Table 1), and healthy controls (14 cases; Table 1) were $42.6 \pm 15.4$, $41.5 \pm 8.6$, and $35.9 \pm 11.6$ years, respectively.

\section{Sampling protocol}

PBMCs were cultured for 2 days in RPMI1640/10\% FBS with $0.1 \mu \mathrm{g} / \mathrm{mL}$ cyclosporin $\mathrm{A}$ at $37^{\circ} \mathrm{C}$, as described previously $(4,19,20)$, to suppress $\mathrm{T}$ cell function and enrich the B cell population. They were then transferred to a culture at $33^{\circ} \mathrm{C}$ to induce $\mathrm{EBV}$ reactivation and were regarded as day 0 samples. A culture at $33^{\circ} \mathrm{C}$ has been shown to physiologically induce EBV reactivation $(9,20,26,27)$.

On days $0,5,10$, and 12 , half of the culture fluid was sampled and replaced with fresh medium (Fig. 2). Culture cells were collected on days 0 and 5 for flowcytometry (FCM) and confocal laser microscopy.

In the 11 common subjects of our previous and present studies, the culture fluids used in this study were the same aliquots as those in the previous study.

\section{Ig measurements in culture medium and serum}

We measured IgG4 concentrations in the culture medium using an ELISA kit (Affymetrix eBioscience, Vienna, Austria) and IgG concentrations using ELISA (Bethyl No. E80-104, E80-100, E80-108; Montgomery, TX) according

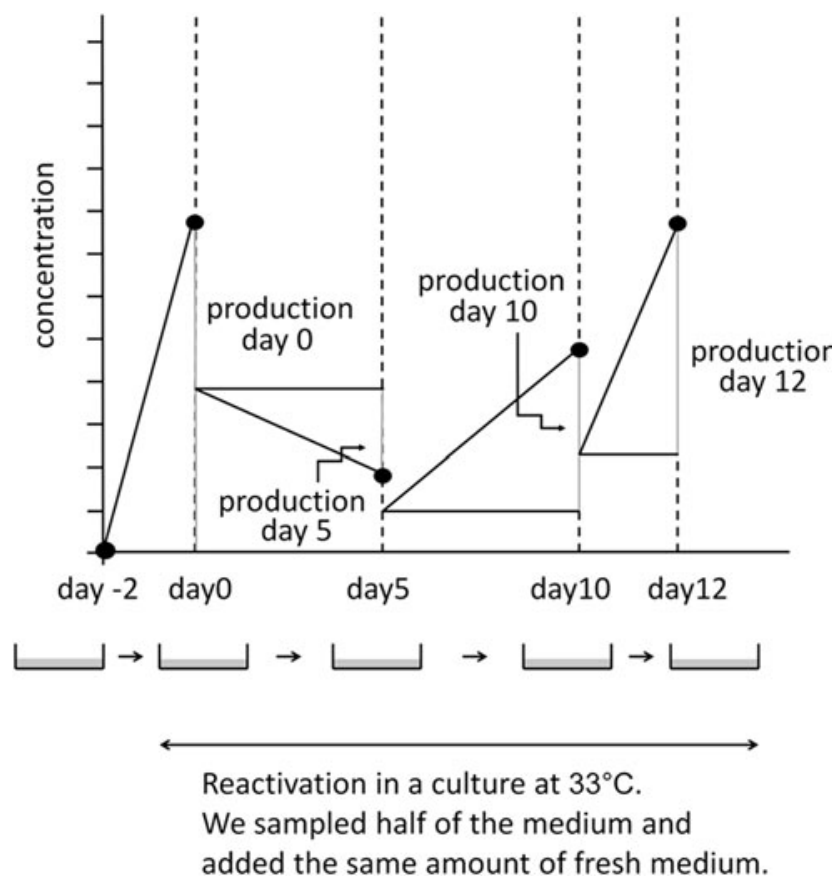

FIG. 2. Sampling protocol. We cultured PBMCs at $33^{\circ} \mathrm{C}$ to induce $\mathrm{EBV}$ reactivation. On days $0,5,10$, and 12 , we collected half of the medium for examination and added the same amount of the fresh medium. Ig production at each sampling point was assessed by subtracting half of the values of the previous point from those at the sampling point. Adapted from Nagata $e t$ al. (20). PBMCs, peripheral blood mononuclear cells. to the manufacturer's instructions. On the days when the culture medium was sampled, we collected half of the medium for examinations and added the same amount of the fresh medium (Fig. 2). Ig production at each sampling point was assessed by subtracting half of the values of the previous point from those at the sampling point.

\section{FCM and confocal laser microscopy}

The culture cells collected were fixed by $2 \%$ paraformaldehyde and fluorostained by a 72A1 mouse monoclonal antibody (Millipore, Temecula, CA) to detect glycoprotein $350 / 220$ (gp350/220), which is expressed in the late phase of EBV reactivation. Since gp350/220 is also expressed on the host cell surface in this phase $(26,34)$, we used it for FCM (Supplementary Fig. S1; Supplementary Data are available online at www.liebertpub.com/vim).

Cells were incubated with $3 \mu \mathrm{L} / 10^{6}$ cells of $72 \mathrm{~A} 1$ at $4^{\circ} \mathrm{C}$ for $30 \mathrm{~min}$. After the incubation, they were washed and incubated with $1 \mu \mathrm{g} / 106$ cells of goat anti-mouse IgG H\&L (Alexa Fluor ${ }^{\circledR}$ 488) (Abcam, Cambridge, United Kingdom) as a secondary antibody.

We used $1 \mu \mathrm{g} / 10^{6}$ cells of an anti-human IgG4 rabbit monoclonal antibody, clone RM120 (Abnova, Taipei, Taiwan) to stain surface IgG4, and $1 \mu \mathrm{g} / 10^{6}$ cells of goat antirabbit IgG $\left(\mathrm{H}+\mathrm{L}\right.$ ) (Alexa Fluor ${ }^{\circledR}$ 647) (Invitrogen, Carlsbad, CA) as a secondary antibody.

Fluorostained samples were analyzed and sorted with the cell sorter, MoFlo XDP (Beckman Coulter, Fullerton, CA).

IgG4(+)72A1(+) cells were sorted and examined using the confocal laser microscope, TCS SP-2 (Leica, Wetzlar, Germany).

\section{In situ hybridization and immunohistochemistry}

Seven of the 11 cases underwent thyroidectomy showed focal moderate lymphoplasmacytic infiltration in the hyperplastic thyroid gland. In situ hybridization and immunohistochemistry were performed on these seven cases only.

The in situ hybridization of EBV-encoded small RNA1 (EBER1) was performed with EBER1-PNA Probe/Fluorescein (Y5200; Dako, Glostrup, Denmark), and immunohistochemistry for $\operatorname{IgG} 4$ and $\operatorname{IgG}$ was conducted with the anti-human IgG4 rabbit monoclonal IgG, clone RM120 (Abnova), and anti-human IgG mouse monoclonal IgMк (A57H) (Nichirei, Tokyo, Japan). Envision Dual Link System-HRP (K4063) (Dako) was used for a secondary antibody.

\section{Statistical analyses}

Statistical analyses were performed using SPSS Statistics 21 (IBM, Armonk, NY).

Friedman's test was adopted to analyze time course variations in Ig concentrations. The Mann-Whitney $U$ test was used to compare IgG4 percentage (IgG4/total IgG\%) peaks.

\section{Results}

\section{IgG4 production was stimulated by EBV reactivation}

We added three controls and four patients to the common subjects and obtained the same significant change of total IgG (Friedman's analysis: $p=0.000$ for controls and $p=0.003$ for patients) as previous report (Fig. 3A). 

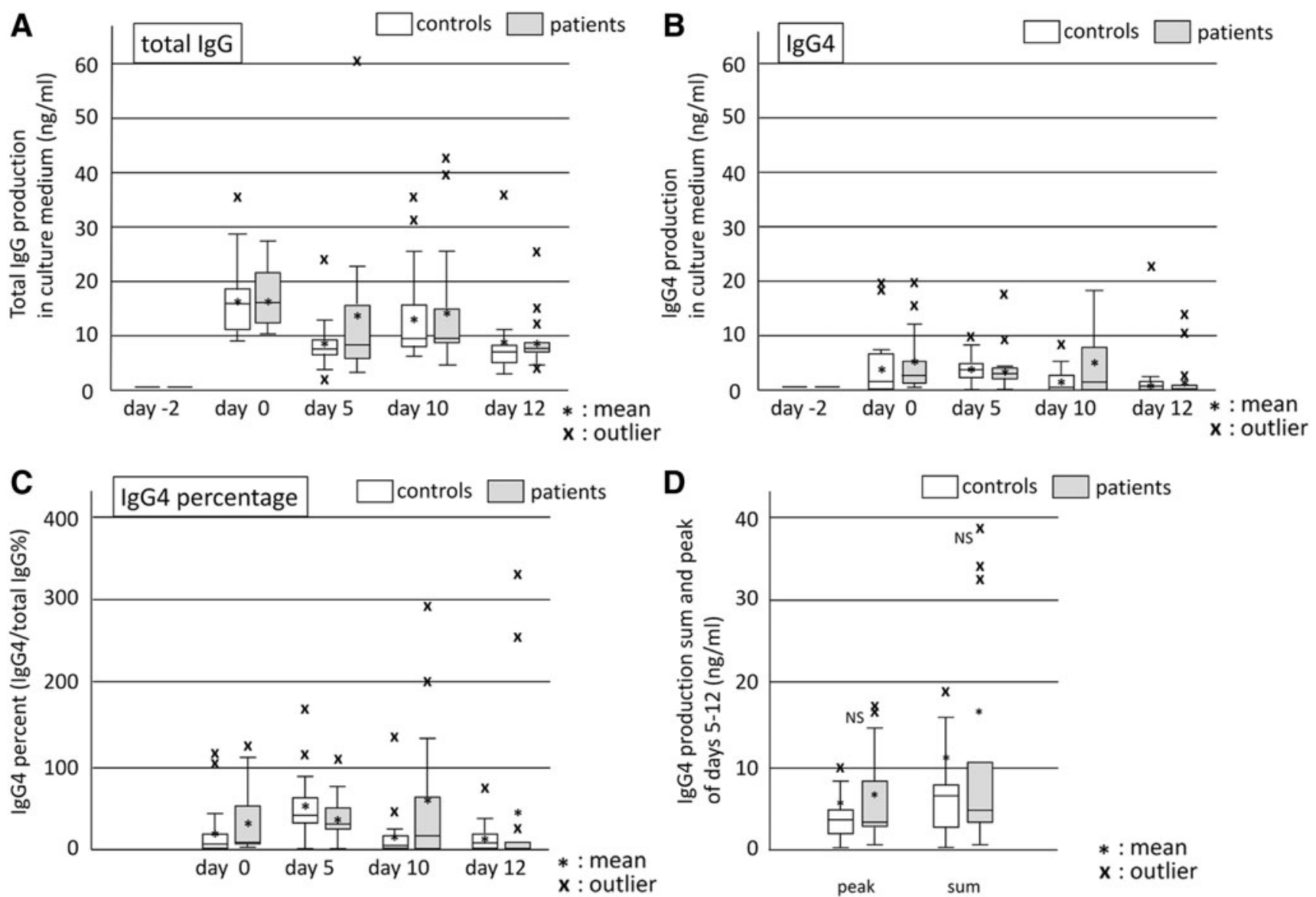

FIG. 3. Production of IgG and IgG4 during the EBV reactivation period. Culture fluids were sampled on days 0 , 5, 10, and 12 , and $\operatorname{IgG}(\mathbf{A})$ and IgG4 (B) were then measured by ELISA. Time course changes were significant in Friedman's analysis of variance. IgG4 percentages (C) were higher than normal serum levels (approximately 4\%). However, no significant difference was observed between patients and controls (D).

IgG4 levels significantly changed during the sampling period (Friedman's analysis: $p=0.005$ for controls and $p=0.007$ for patients) with the first peak being observed on day 0 (Fig. 3B). Since the induction of EBV reactivation started at day 0, PBMCs on day 0 did not receive stimulation for reactivation. We confirmed that these PBMCs on day 0 contain $4-12 \%$ of CD38(+) cells or CD138(+) cells in our previous study (22). Therefore, the day 0 peak represented the production from plasma cells or activated B cells that were already present, and the production stimulated by EBV reactivation was that with peaks on days 5, 10, and 12. Patients and controls showed production with peaks on day 5 or 10 , indicating $\mathrm{IgG} 4$ production stimulated by EBV reactivation.

IgG, IgM, and IgG4 levels on day-2 (start point) were the same as those of the negative control $(0 \mathrm{ng} / \mathrm{mL}$ of ELISA standard); therefore, we disregarded the effects of Igs originally in the culture medium.

\section{Culture cells on day 5 contained lgG4(+)72A1(+) double-positive cells}

There were $9.88 \%$ of $72 \mathrm{~A} 1(+)$ cells in day 5 cells (mean of 4 samples), suggesting that cells on day 5 were affected by the induction of reactivation (Supplementary Table S1).

We noted red spots of IgG4 on IgG4(+)72A1(+) doublepositive cell surfaces and fine green dots on cell surfaces and in the cytoplasm that represented the 72A1 antibody binding to EBV-gp350/220 (Fig. 4 and Supplementary Fig. S1).

\section{IgG4 percentage (IgG4/lgG) in culture fluids increased during $E B V$ reactivation}

On day 0 (before reactivation), mean $\mathrm{IgG} 4$ percentages in patients and controls were $\sim 35.88 \%$ and $\sim 23.99 \%$, respectively. During reactivation, they increased to $\sim 60.59 \%$ in patients (day 10) and $\sim 56.19 \%$ in controls (day 5) (Fig. 3C).

The normal value of serum $\mathrm{IgG} 4 / \mathrm{IgG}$ has been reported to be approximately $4 \%$ (25). IgG4 production induced by EBV reactivation resulted in the greater percentage than serum levels.

\section{Comparison of IgG4 production between patients and controls}

We compared IgG4 production in patients and controls by peaks and sums during reactivation. They were slightly higher in patients than in controls, but they were not significant (Fig. 3D).

\section{EBER1-positive cells and IgG4-positive cells were observed in the same areas}

The pathological findings of resected tissues were the diffuse hyperplasia of thyroid glands in all 11 cases, with 7 


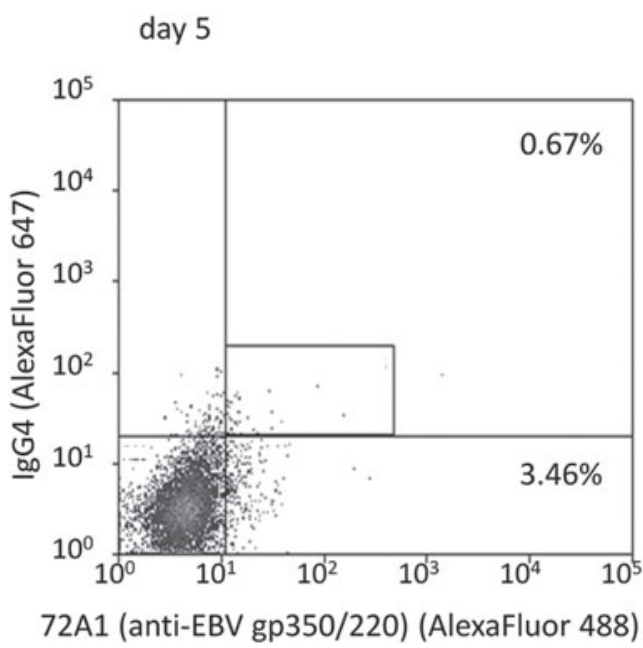

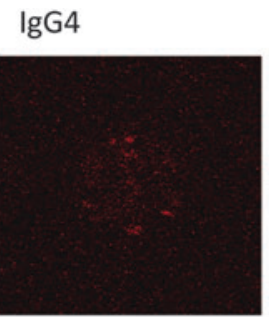

DAPI

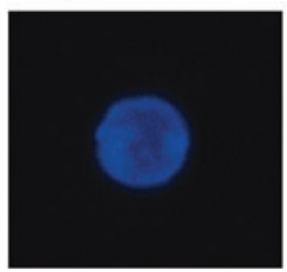

$72 \mathrm{~A} 1$

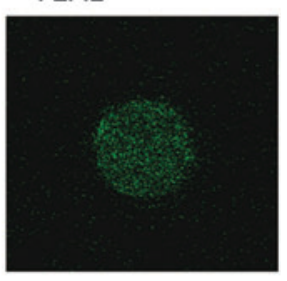

merged

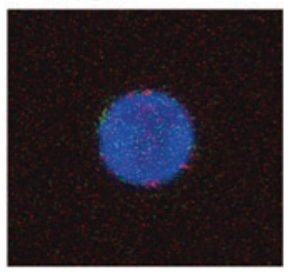

FIG. 4. Detection of IgG4(+)72A1(+) double-positive cells in culture cells on day 5. We detected IgG4-positive and EBVreactivated $[\operatorname{IgG} 4(+) 72 \mathrm{~A} 1(+)]$ cells in culture cells on day 5 and confirmed sorted cells by confocal laser microscope. Red spots are surface IgG4 and fine green dots are 72A1 antibodies binding to EBV-gp350/220. The frequency of 72A1(+) cells of this sample (representative case; patient 3) was $4.13 \%(0.67+3.46)$, and the mean frequency of four samples was $9.88 \%$ (Supplementary Table S1).

of the 11 cases showing the focal moderate infiltration of lymphoplasmacytic cells, and most cases also had lymphoid follicles. However, we did not detect tumefactive lesions, storiform fibrosis, or obliterative phlebitis. The immunohistochemistry of seven cases with moderate lymphoid cell infiltration revealed that EBER1-positive

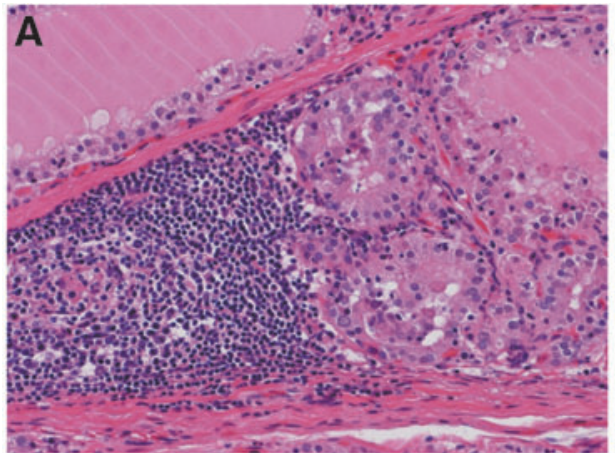

HE

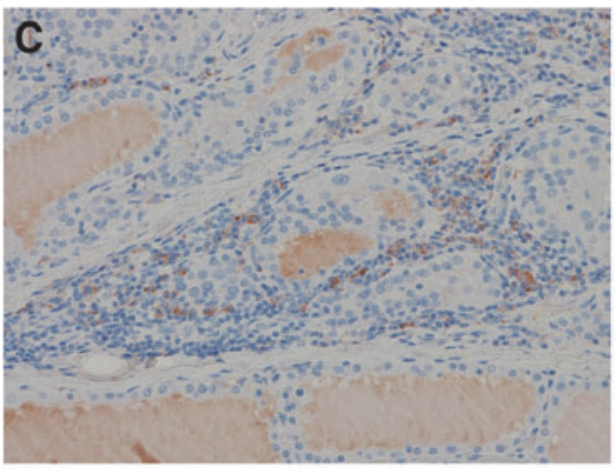

IgG cells and IgG4-positive plasma cells were present in the same area with lymphoid cell infiltration (Fig. 5; Table 2). Six of the seven cases had a large number of IgG4-positive plasma cells (over 10 cells in a high power field $[10<\mathrm{HPF}<]$ ) and the ratio of $\operatorname{IgG} 4(+)$ cells/IgG $(+)$ cells was greater than $40 \%$.

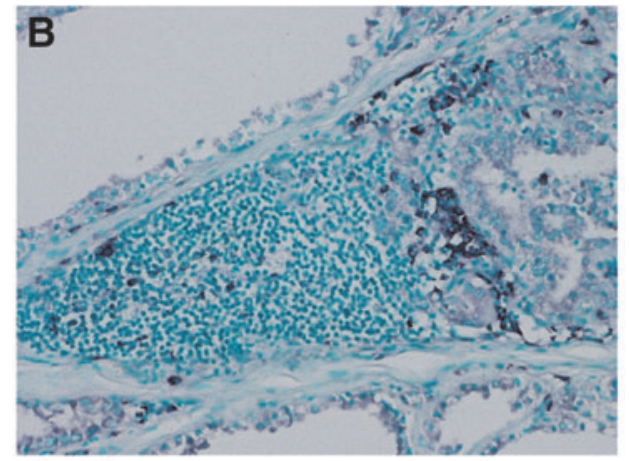

\section{EBER1}

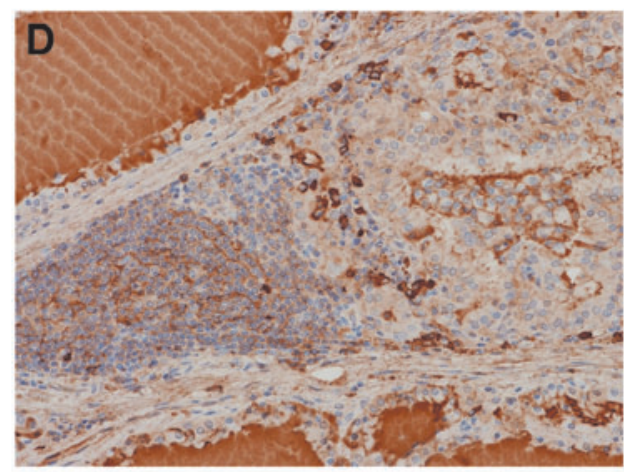

$\operatorname{lgG} 4$

FIG. 5. EBER1-positive cells and IgG4-positive cells were observed in the same areas. Resected tissues showed the diffuse hyperplasia of thyroid follicular epithelial cells with the focal infiltration of lymphocytes, but not tumefactive lesions, storiform fibrosis, or obliterative phlebitis (A). EBER1-positive cells and IgG4-positive plasma cells were observed in the same area with lymphoid cell infiltration (B, D). Six of the seven cases had a large number of IgG4-positive plasma cells $(10 / \mathrm{HPF}<)$, and the ratio of $\operatorname{IgG} 4(+)$ cells/IgG(+) cells was greater than $40 \%(\mathbf{C}, \mathbf{D})$. EBER1, EBV-encoded small RNA1; HPF, high power field. 


\section{Discussion}

Eleven of the 24 Graves' disease patients underwent thyroidectomy due to difficulties associated with controlling their thyroid function with antithyroid drugs. Eleven resected specimens exhibited diffuse hyperplasia, and 7 of the 11 cases had the focal moderate infiltration of lymphocytes with lymphoid follicle formation (Fig. 5A). This lymphoid cellular infiltration contained a similar number of IgG4positive plasma cells to that of IgG4-RD (Fig. 5D; Table 2). IgG4 serum levels in our patients who underwent thyroidectomy were high, particularly in three patients with levels higher than $135 \mathrm{mg} / \mathrm{dL}$, which were also similar to IgG4-RD (Table 2). However, we did not detect tumefactive lesions, storiform fibrosis, or obliterative phlebitis. Therefore, Graves' disease is not an IgG4-RD, but a subset of Graves' disease is an IgG4-RD-like condition.

This is consistent with previous findings showing that some patients with Graves' disease (31) show high serum IgG4 levels. Most of our cases of thyroidectomy had very high levels of TRAbs as well as IgG4.

During the induction of EBV reactivation on PBMCs from patients and controls, we observed EBV-reactivated cells with IgG4 on their surface $[\operatorname{IgG} 4(+) 72 \mathrm{~A} 1(+)$ cells]. In the culture fluid of PBMCs containing IgG4(+)72A1(+) cells, we detected IgG4 in addition to IgG, IgM, and IgE (Table 1; Fig. 3) [previous report: (22)], which indicated that IgG4 was also produced by an EBV reactivation-induced Ig production, the alternative system of antibody production. AID, necessary for CSR, is supplied during EBV reactivation because EBV newly infected $B$ cell can be activated and express EBVLMP1 that promotes the expression of AICDA mRNA through nuclear factor-kappa B (NF- $\kappa \mathrm{B})(7,18,22,36)$ (Fig. 1). The CSR to IgG4 (Supplementary Fig. S2) requires $\mathrm{T}_{\mathrm{H}} 2$ cytokines and IL-10 from regulatory $\mathrm{T}$ cells (Treg) $(1,24)$. The EBV$B C R F 1$ gene product exhibits high homology to IL-10 (8), and EBERs stimulate the expression of human IL-10 from host B cells (28). Viral and human IL-10 may be attributed to IgG4 production instead of Treg cells.

In contrast to the small percentage of normal serum IgG4 in total $\operatorname{IgG}$ (approximately 4\%) (25), the mean values of $\mathrm{IgG} 4 / \mathrm{IgG}$ in the culture fluid during the observation period were more than $15 \%$ (Fig. 3C). Several cases showed that most of the IgG produced was IgG4, accounting for differences in the sensitivities of the antibodies used in IgG4 ELISA and IgG ELISA. Our results suggest that EBV reactivation-induced $\mathrm{Ig}$ production generates a higher percentage of IgG4 than typical Ig production.

In typical Ig production, plasma cells produce highaffinity IgG antibodies $(17,25)$, but IgG4 is not a highaffinity antibody $(2,33,35)$. Therefore, it may only rarely be selected in affinity maturation. IgG4-positive plasma cells that infiltrate inflammatory tissues may have differentiated through another process, not the germinal center reaction.

Our results showed that EBV reactivation stimulates IgG4 production in a subset of Graves' disease, and in some cases, it may be the main source of IgG4. Therefore, high serum IgG4 levels and the infiltration of IgG4-positive plasma cells observed in IgG4-RD-like conditions may be present as a consequence of chronic inflammation and EBV reactivation.

Immunohistochemistry and in situ hybridization revealed that EBER1-positive cells were present in the thyroid glands of Graves' disease patients with lymphocyte infiltration (Fig. 5B; Table 2). We detected IgG4-positive plasma cells at more than 10 cells/HPF in the same area (Fig. 5D; Table 2). These results are consistent with previous reports showing that the number of EBV-positive cells increased in IgG4-related lymphadenopathy (30) and that a case of Graves' disease with severe hypothyroidism had characteristics of IgG4-RD (23).

Histologically, there are two types of Graves' autoimmune hyperthyroidism, the one with lymphocytic infiltration and the other with no significant inflammatory infiltration. In this study, we noticed EBER1-positive cells and IgG4-positive plasma cells in the same area with lymphocyte infiltration. Besides, we did not find any tumors or inflammatory diseases except for thyroid gland in all our subjects clinically. Therefore, it is one interpretation that IgG4 may be induced by EBV reactivation in Graves' disease with lymphocytic infiltration as a thyroid-specific IgG4 thyroiditis $(10,14,15,23)$. However, as we showed EBV reactivation-induced IgG4 production in cultured PBMCs, IgG4 production may occur in circulation as well as in local thyroid tissue with lymphoplasmacytic infiltration in a chronic inflammatory condition with EBV reactivation.

Therefore, EBV may also contribute to the mechanisms underlying IgG4 production, even in systemic IgG4-RD $(12,32)$; however, further investigations are required. We need to examine EBER1 in situ hybridization to confirm the infiltration of EBV-infected B cells when an increase in IgG4-positive plasma cells is noted.

\section{Acknowledgments}

We are grateful to Dr. Shuji Fukata (Kuma Hospital) and former professor Takeshi Sairenji (Tottori University). We also thank the Medical English Service (Kyoto, Japan) for proofreading this article. This work was supported by the Tottori University Faculty of Medicine Research Grant (2015), Discretionary funds of the director of Tottori University Hospital (2016), and JSPS KAKENHI Grant No. 17K08694 (K.N.).

\section{Author Disclosure Statement}

No competing financial interests exist.

\section{References}

1. Aalberse RC, Stapel SO, Schuurman J, and Rispens T. Immunoglobulin G4: an odd antibody. Clin Exp Allergy 2009;39:469-477.

2. Canfield SM, and Morrison SL. The binding affinity of human $\mathrm{IgG}$ for its high affinity Fc receptor is determined by multiple amino acids in the $\mathrm{CH} 2$ domain and is modulated by the hinge region. J Exp Med 1991;173:1483-1491.

3. Cohen JI. Epstein-Barr virus infection. NEJM 2000;343: 481-492.

4. Frisan T, Levitsky V, and Masucci M. Generation of lymphoblastoid cell lone (LCLs). In: Wilson J, May GHW (eds.). Epstein-Barr Virus Protocols (Method in Molecular Biology, Vol. 174). Totowa: Humana Press, 2001:125-127.

5. Haldar D, and Hirschfield GM. Deciphering the biology of IgG4-related disease: specific antigens and disease? Gut 2018;67:602-605. 
6. Hamano H, Kawa S, Horiuchi A, et al. High serum IgG4 concentrations in patients with sclerosing pancreatitis. $\mathrm{N}$ Engl J Med 2001;344:732-738.

7. He B, Raab-Traub N, Casali P, and Cerutti A. EBVencoded latent membrane protein 1 cooperates with BAFF/ BLyS and APRIL to induce T cell-independent Ig heavy chain class switching. J Immunol 2003;171:5215-5224.

8. Henle W, Henle G, and Horwitz C. Epstein-Barr virus specific diagnostic tests in infectious mononucleosis. Hum Pathol 1974;5:551-565.

9. Hinuma Y, Konn M, Yamaguchi J, et al. Immunofluorescence and herpes-type virus particles in the P3HR-1 Burkitt lymphoma cell line. J Virol 1967;1:1045-1051.

10. Kakudo K, Li Y, Taniguchi E, et al. IgG4-related disease of the thyroid glands. Endocr J 2012;59:273-281.

11. Kenney SC, and Mertz JE. Regulation of the latent-lytic switch in Epstein-Barr virus. Semin Cancer Biol 2014;26: 60-68.

12. Komatsu K, Hamano H, Ochi Y, et al. High prevalence of hypothyroidism in patients with autoimmune pancreatitis. Dig Dis Sci 2005;50:1052-1057.

13. Latrofa F, Chazenbalk GD, Pichurin P, Chen CR, and McLachlan SM. Rapoport B Affinity-enrichment of thyrotropin receptor autoantibodies from Graves' patients and normal individuals provides insight into their properties and possible origin from natural antibodies. J Clin Endocrinol Metab 2004;89:4734-4745.

14. Li Y, Nishihara E, Hirokawa M, et al. Distinct clinical, serological, and sonographic characteristics of hashimoto's thyroiditis based with and without IgG4-positive plasma cells. J Clin Endocrinol Metab 2010;95:1309-1317.

15. Li Y, Zhou G, Ozaki T, et al. Distinct histopathological features of Hashimoto's thyroiditis with respect to IgG4related disease. Mod Pathol 2012;25:1086-1097.

16. Longnecker RM, Kieff E, and Cohen J. Epstein-Barr virus. In: Knipe DM, Howley PM, eds. Fields Virology. 6th ed. Philadelphia: Lippincott Williams \& Wilkins, 2013:18981959.

17. Manz RA, Thiel A, and Radbruch A. Lifetime of plasma cells in the bone marrow. Nature 1997;388:133-134.

18. Muramatsu M, Kinoshita K, Fagarasan S, et al. Class switch recombination and hypermutation require activation-induced cytidine deaminase (AID), a potential RNA editing enzyme. Cell 2000;102:553-563.

19. Nagata K, Higaki K, Nakayama Y, et al. Presence of EpsteinBarr virus-infected B lymphocytes with thyrotropin receptor antibodies on their surface in Graves' disease patients and in healthy individuals. Autoimmunity 2014;47:193-200.

20. Nagata K, Nakayama Y, Higaki K, et al. Reactivation of persistent Epstein-Barr virus (EBV) causes secretion of thyrotropin receptor antibodies (TRAbs) in EBV-infected B lymphocytes with TRAbs on their surface. Autoimmunity 2015;48:328-335.

21. Nagata K, Okuno K, Ochi M, et al. Production of thyrotropin receptor antibodies in acute phase of infectious mononucleosis due to Epstein-Barr virus primary infection: a case report of a child. Springerplus 2015;4:456 eCollection.

22. Nagata K, Kumata K, Nakayama $\mathrm{Y}$, et al. Epstein-Barr virus lytic reactivation activates $\mathrm{B}$ cells polyclonally and induces activation-induced cytidine deaminase expression: a mechanism underlying autoimmunity and its contribution to Graves' disease. Viral Immunol 2017;30:240-249.
23. Nishihara E, Hirokawa M, Takamura $\mathrm{Y}$, et al. Immunoglobulin G4 thyroiditis in a Graves' disease patient with a large goiter developing hypothyroidism. Thyroid 2013;23:1496-1497.

24. Nirula A, Glaser SM, Kalled SL, and Taylor FR. What is IgG4? A review of the biology of a unique immunoglobulin subtype. Curr Opin Rheumatol 2011;23:119-124.

25. Parham P. The Immune System, 3rd ed. New York: Garland Science, 2009.

26. Sairenji T, Bertoni G, Medveczky MM, Medveczky PG, and Humphreys RE. Inhibition of Epstein-Barr virus (EBV) release from P3HR-1 and B95-8 cell lines by monoclonal antibodies to EBV membrane antigen gp350/220. J Virol 1988;62:2614-2421.

27. Sairenji T, and Hinuma Y. Re-evaluationof a transforming strain of Epstein-Barr virus from the Burkitt lymphoma cell line, Jijoye. Int J Cancer 1980;26:337-342.

28. Samanta M, Iwakiri D, and Takada K. Epstein-Barr virusencoded small RNA induces IL-10 through RIG-I-mediated IRF-3 signaling. Oncogene 2008;27:4150-4160.

29. Stone JH, Zen Y, and Deshpande V. IgG4-related disease. N Engl J Med 2012;366:539-551.

30. Takeuchi M, Sato Y, Yasui H, et al. Epstein-Barr virusinfected cells in IgG4-related lymphadenopathy with comparison with extranodal IgG4-related disease. Am J Surg Pathol 2014;38:946-955.

31. Takeshima K, Inaba H, Furukawa Y, et al. Elevated serum immunoglobulin G4 levels in patients with Graves' disease and their clinical implications. Thyroid 2014;24:736-743.

32. Takeshima K, Ariyasu H, Inaba $\mathrm{H}$, et al. Distribution of serum immunoglobulin G4 levels in Hashimoto's thyroiditis and clinical features of Hashimoto's thyroiditis with elevated serum immunoglobulin G4 levels. Endocr J 2015; 62:711-717.

33. Tao MH, Smith RI, and Morrison SL. Structural features of human immunoglobulin $\mathrm{G}$ that determine isotype-specific differences in complement activation. J Exp Med 1993;178: 661-667.

34. Thorley-Lawson DA, and Geilinger K. Monoclonal antibodies against the major glycoprotein (gp350/220) of Epstein-Barr virus neutralize infectivity. Proc Natl Acad Sci 1980;77:5307-5311.

35. van der Neut Kolfschoten M, Schuurman J, Losen M, et al. Anti-inflammatory activity of human IgG4 antibodies by dynamic Fab arm exchange. Science 2007;317:1554-1557.

36. Zhenming X, Pone EJ, Al-Qahtani A, et al. Regulation of aicda expression and AID activity: relevance to somatic hypermutation and class switch DNA recombination. Crit Rev Immunol 2007;27:367-397.

Address correspondence to: Dr. Keiko Nagata

Division of Molecular Pathology Department of Pathology Faculty of Medicine Tottori University 86 Nishi-Cho Yonago 683-8503 Japan

E-mail: nanamon@ theia.ocn.ne.jp 